\title{
Habitat availability is not limiting the distribution of the Bohemian-Bavarian lynx Lynx lynx population
}

\author{
Nora Magg, Jörg Müller, Christoph Heibl, Klaus Hackländer \\ Sybille Wölfi, Manfred Wölfi, Ludêk Bufka \\ JAROSLAV ČERVENÝ and MARCO HEURICH
}

\begin{abstract}
A population of Eurasian lynx Lynx lynx was established by reintroductions in the Bohemian Forest Ecosystem in the 1970 and 1980 os. The most recent information on the population status indicates that the distribution has stagnated since the late 1990s, for unknown reasons. We assessed the availability of suitable habitat along the Austrian-German-Czech border, and hypothesized that the Bohemian-Bavarian lynx population is not in equilibrium with habitat suitability. Based on global positioning system data from 10 radio-collared lynx, we used a maximum entropy approach to model suitable habitat. Variables reflecting anthropogenic influence contributed most to the model and were negatively associated with the occurrence of lynx. We evaluated the model prediction using independent records of lynx from monitoring in Bavaria, Germany. Using our habitat approach we estimated the area of potential habitat, based on a mean annual home range of $445 \mathrm{~km}^{2}$ for males and $122 \mathrm{~km}^{2}$ for females. Our results indicated there were $12,415 \mathrm{~km}^{2}$ of suitable habitat, distributed among 13 patches, for a potential population of
\end{abstract}

NORA MAGG ${ }^{*} \ddagger$ (Corresponding author) and JÖRG MÜLLER $\dagger$ Bavarian Forest National Park, Freyunger Str. 2, 94481 Grafenau, Germany

E-mail nora.m@gmx.net

Christoph Heibl Department of Ecology and Ecosystem Management, Technische Universität München, Freising, Germany

Klaus HaCKLÄNDER Department of Integrative Biology and Biodiversity Research, Institute of Wildlife Biology and Game Management, University of Natural Resources and Life Sciences, Vienna, Austria

Sybille Wölfl Lynx Project Bavaria, Lam, Germany

Manfred WöLfl Bavarian Environmental Agency, Hof/Saale, Germany

LudÊK BufKa§ Šumava National Park, Kašperské Hory, Czech Republic

JAROSLAV ČERVENÝ Faculty of Forestry and Wood Sciences, Czech University of Life Sciences Prague, Czech Republic

Marco Heurich** Bavarian Forest National Park, Grafenau, Germany

*Also at: Department of Integrative Biology and Biodiversity Research, Institute of Wildlife Biology and Game Management, University of Natural Resources and Life Sciences, Vienna, Austria

$\dagger$ Also at: Department of Ecology and Ecosystem Management, Technische Universität München, Freising, Germany

§Also at: Faculty of Forestry and Wood Sciences, Czech University of Life Sciences Prague, Czech Republic

${ }^{*}$ Also at: Chair of Wildlife Ecology and Management, University of Freiburg, Faculty of Environment and Natural Resources, Freiburg, Germany

¥Current address: Forest Research Institute of Baden-Württemberg, Freiburg, Germany

Received 4 October 2014. Revision requested 28 October 2014.

Accepted 16 March 2015. First published online 6 August 2015. c. 142 (93-160) resident lynx. We assessed connectivity via least-cost paths and found that all suitable patches could be reached by the lynx. A comparison with the current distribution of lynx, however, confirms that a significant proportion of suitable habitat is not occupied, which indicates that the distribution is limited by factors other than habitat, with illegal killing being the most likely cause. Our study provides crucial information for the development of a conservation strategy and regional planning for the BohemianBavarian lynx population.

Keywords Habitat connectivity, home range, large carnivore conservation, least-cost paths, Lynx lynx, radio tracking, species distribution modelling

To view supplementary material for this article, please visit http://dx.doi.org/10.1017/Soo30605315000411

\section{Introduction}

fter decades of persecution and extermination of large carnivores in Europe, populations have started to recover (Chapron et al., 2014). Management policy has improved considerably and large carnivores are protected by law in most European countries (Molinari-Jobin et al., 2010). They are recolonizing their former ranges both naturally and through reintroduction (Linnell et al., 2001); however, they are confronted with a human-dominated landscape, where their habitats are diminished and fragmented as a result of direct destruction and the development of roads and railways (Fischer \& Lindenmayer, 2007). With the reduction in habitat, wildlife populations become smaller and more isolated, both of which increase the risk of local extinction. Large carnivores are particularly vulnerable to local extinction in fragmented environments because they require large contiguous spaces, and their populations are low in density (Ripple et al., 2014).

For the Eurasian lynx Lynx lynx, stagnation and declines of reintroduced and formerly increasing populations have been reported (e.g. the Vosges-Palatinian population in France; the Dinaric population in Slovenia, Croatia, Bosnia and Herzegovina; the Bohemian-Bavarian population along the Austrian-German-Czech border; Kaczensky et al., 2013). The latter population originated from lynx captured in the Carpathian Mountains and reintroduced to the 
Bohemian Forest in the 1970s and 1980s (Wölfl et al., 2001). The population resides in the Bohemian Forest Ecosystem, in which the Bavarian Forest National Park and the Sumava National Park are embedded. Initially data indicated an increase in numbers and distribution but at the end of the 1990 s population increase stagnated, and in the Czech part of the Bohemian Forest the number of individuals decreased (Wölfl et al., 2001). The latest status report on the population also presumes stagnation in population size and range in Germany and Austria. It is estimated the Bohemian-Bavarian population comprises 47-67 individuals (Kaczensky et al., 2013).

The reason for the stagnation of this population is of concern for lynx conservation in Central Europe because of the population's central geographical location and thus its potential to act as a link between other small and isolated populations. Isolation of a small population may result in reduced genetic variability, lower reproductive success and increased risk of extinction (Schmidt, 2008). Humaninduced mortality may have an even greater impact than low reproductive success (Linnell et al., 2001), particularly mortality caused by road traffic or illegal killing (Andrén et al., 2006; Molinari-Jobin et al., 2010; Müller et al., 2014). Habitat availability and connectivity may influence population dynamics and thus may be the factor limiting the distribution of the Bohemian-Bavarian lynx.

Information on the spatial distribution, size and connectivity of suitable habitat patches is a prerequisite when comparing actual and potential lynx distribution to maximize the success of population conservation. Models based on a geographical information system provide an effective means of gathering information about spatial distribution and expanse of potential habitat. Previous analyses of lynx habitat have highlighted the importance of forests, and the negative association of lynx presence with habitat fragmentation, human settlements and areas of intensive land use (Niedziałkowska et al., 2006; Breitenmoser-Würsten et al., 2007; Basille et al., 2009). In previous models of lynx habitat in Germany habitat suitability was assessed based on the availability of forest cover (Schadt et al., 2002a), and using VHF-telemetry data for 13 lynx in the Swiss Jura Mountains (Schadt et al., 2002b). Thus there was a risk of predictive uncertainty because the model was extrapolated beyond the domain of the data (Pearson et al., 2006). At the time of our study, novel techniques for species distribution modelling and global positioning system (GPS) telemetry data for lynx of the Bohemian-Bavarian population were available, which facilitated a qualified assessment of habitat in this area by staying within the domain of the data (Guisan \& Zimmermann, 200o). Müller et al. (2014) analysed monitoring data for lynx in Bavaria and found occurrence of lynx was predicted most clearly by proximity to national park areas. Whereas these authors sought predictors to explain lynx occurrence, we focused on the spatial distribution of suitable habitat and of lynx, and estimated a potential population, considering its entire transnational range.

We developed a habitat suitability model with a maximum entropy approach for the Bohemian-Bavarian lynx population, based on GPS telemetry data for 10 individuals in the region; considered spatial requirements of lynx, using estimates of annual home range; assessed the size and connectivity of suitable habitat patches; estimated a potential population size for the area along the border of Germany, the Czech Republic and Austria; and compared our results with regional occurrence of lynx according to the latest status report (Kaczensky et al., 2013). We used the Bohemian Forest Ecosystem, with its characteristic Central European lynx population and low mountain range habitat, as a model area. Our objective was to provide wildlife managers and administrators involved in the monitoring and management of populations of large carnivores in Europe with a state-of-the-art tool to compile information about local habitat suitability and carrying capacity for the conservation of a population that, as we hypothesize, is not realizing its potential distribution.

\section{Study area}

The Bohemian Forest Ecosystem, Europe's largest region of strictly protected forest, comprises a forested mountain range along the German-Czech border and includes the Bavarian Forest National Park $\left(240 \mathrm{~km}^{2}\right)$ on the German side of the border and the Šumava National Park $(690$ $\mathrm{km}^{2}$ ) on the Czech side (Fig. 1a). Human population densities are comparably low: $<2$ inhabitants per $\mathrm{km}^{2}$ in the National Parks and c. 70 per $\mathrm{km}^{2}$ in nearby regions. Mean annual temperature is $6.7^{\circ} \mathrm{C}$ in montane and $3.9^{\circ} \mathrm{C}$ in subalpine elevation zones. Snow cover persists for $100-200$ days, depending on altitude. GPS data from radio-collared lynx were collected in an area of $2,400 \mathrm{~km}^{2}$ within the Bohemian Forest. This area, defined by the $100 \%$ minimum convex polygon (MCP) of all lynx localizations, served as the model training area (Fig. 1a). Sixty-six percent of this area is covered by forest and $25 \%$ is used for agriculture, primarily grassland. Model prediction covered a more extensive area $\left(110,000 \mathrm{~km}^{2}\right)$ along the borders between Germany, the Czech Republic and Austria (Fig. 1a), 33\% of which is covered with forest and 6o\% used for agriculture.

\section{Methods}

\section{Habitat data}

We configured landscape variables based on CORINE (Coordination of Information on the Environment) land cover 2006 with a resolution of $100 \mathrm{~m}$ (European Environment Agency, 2012). The multiple land-use features 


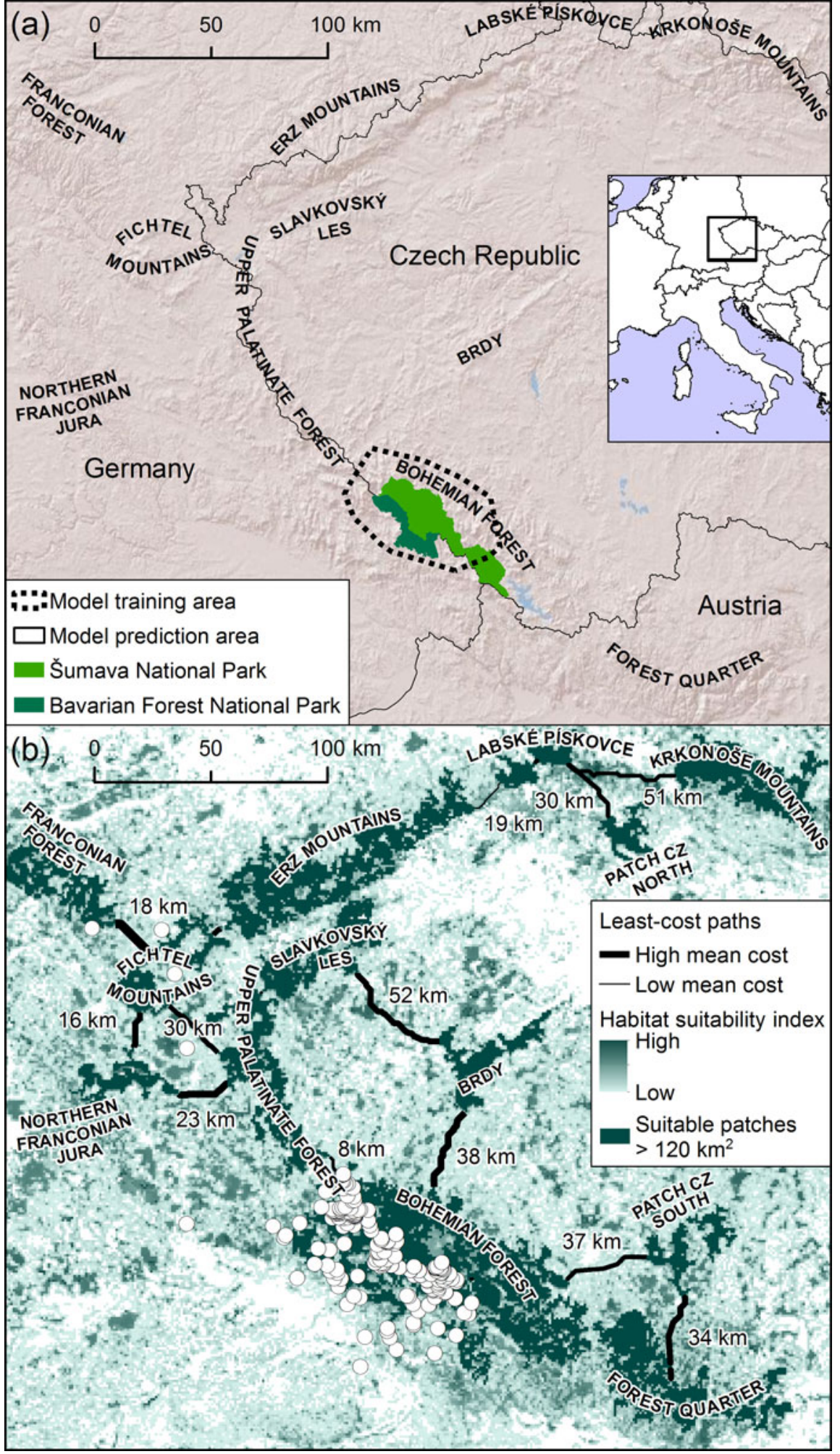

FIG. 1 (a) The study area along the borders between Germany, the Czech Republic and Austria, for which MaxEnt predictions were obtained for distribution of Eurasian lynx Lynx lynx. (b) MaxEnt prediction of habitat suitability for Eurasian lynx in the study area. Patches with habitat suitability index $>0.35$ and a coherent area $>120 \mathrm{~km}^{2}$ are considered suitable (Table 3). Least-cost paths between these patches are indicated. White circles denote records of lynx of Status and Conservation of the Alpine Lynx Population categories $\mathrm{C}_{1}$ and $\mathrm{C}_{2}$, in Bavaria, Germany. of CORINE were pooled into 10 categories (Supplementary Table $\mathrm{S}_{1}$ ). We generated one variable that specified the Euclidean distance to human settlements, and another for altitude (Hijmans et al., 2005; Table 1). All variables were continuous because we calculated land use as the proportion per grid cell to maintain data quality when coarsening spatial resolution (Seebach et al., 2011). We included altitude as a variable because analyses of faecal pellet count indicated a negative correlation between altitude and the density of roe deer Capreolus capreolus 
TABLE 1 Predictor variables used to describe habitats in the Bohemian Forest Ecosystem (Fig. 1a), with their definition, unit, range, and contribution to the MaxEnt model based on GPS data from 10 radio-collared lynx Lynx lynx and environmental variables derived from CORINE land-cover data, given as percentage contribution in regularized log-likelihood distribution compared to a uniform distribution. Estimates were determined at each iteration of the training algorithm (convergence threshold $1 \times 10^{-5}$ ), starting with a uniform distribution. The increase in regularized gain was added to or subtracted from the contribution of the corresponding variable. Product, linear, quadratic and hinge features were used with regularization values of 0.05 for the first three features and 0.5 for the hinge feature (Phillips \& Dudík, 2008; Elith et al., 2011).

\begin{tabular}{|c|c|c|c|c|}
\hline Variable & Definition & Unit & Range & $\begin{array}{l}\% \\
\text { contribution }\end{array}$ \\
\hline Pasture & Pastures & $\%$ & $0-100$ & 23.7 \\
\hline Acre & $\begin{array}{l}\text { Non-irrigated } \\
\text { arable land }\end{array}$ & $\%$ & $0-87$ & 18.7 \\
\hline Altitude & Altitude & $\mathrm{m}$ & $\begin{array}{l}466- \\
1,330\end{array}$ & 15.0 \\
\hline Human & $\begin{array}{l}\text { Human settle- } \\
\text { ments, industry, } \\
\text { artificial surfaces }\end{array}$ & $\%$ & $0-88$ & 11.7 \\
\hline Distanc_hum & $\begin{array}{l}\text { Distance to } \\
\text { human settle- } \\
\text { ments, industry, } \\
\text { artificial surfaces }\end{array}$ & $\mathrm{m}$ & $\begin{array}{l}0- \\
9,444\end{array}$ & 9.1 \\
\hline Woodshrub & $\begin{array}{l}\text { Transitional } \\
\text { woodland shrub \& } \\
\text { wetlands }\end{array}$ & $\%$ & $0-100$ & 5.8 \\
\hline Forestconif & Coniferous forest & $\%$ & $0-100$ & 4.4 \\
\hline Naturalagri & $\begin{array}{l}\text { Agricultural areas } \\
\text { with significant } \\
\text { natural vegetation } \\
\text { or complex culti- } \\
\text { vation patterns }\end{array}$ & $\%$ & $0-84$ & 4.4 \\
\hline Forestmix & Mixed forest & $\%$ & $0-100$ & 2.9 \\
\hline Forestleaves & $\begin{array}{l}\text { Broad-leaved } \\
\text { forest }\end{array}$ & $\%$ & $0-94$ & 2.6 \\
\hline Natgrassl & Natural grassland & $\%$ & $0-100$ & 1.8 \\
\hline Water & $\begin{array}{l}\text { Inland water } \\
\text { bodies }\end{array}$ & $\%$ & $0-48$ & 0 \\
\hline
\end{tabular}

(Heurich et al., 2015), which is the main prey of the regional lynx (Heurich et al., 2012).

\section{Lynx presence data}

The habitat model was based on GPS data from 10 radiocollared lynx (six males and four females). The animals were caught in baited box traps and fitted with GPS-GSM collars (VECTRONIC Aerospace, Berlin, Germany; see Podolski et al. (2013) for details). The lynx were collared during 2005-2012; the operating time of individual collars was 3.5-16 months. To limit autocorrelation we standardized sampling frequency to one location per day and randomly sampled without replacement 350 locations for each individual to avoid uneven contribution. However, for three individuals only 85,146 and 255 locations were available, resulting in a total of 2,936 locations used. These provided information about daytime resting sites as well as crepuscular and nocturnal habitat use. We assume that the locations used represent a random sample of lynx occurrence because, in a test, reception of GPS collars in various habitats was high (99\%) and independent of habitat structure (Heurich et al., unpubl. data).

With repeated sampling of one individual it may be necessary to consider the individuality of the lynx. As MaxEnt does not include random effects, we fitted a generalized linear mixed model beforehand to examine individuality. Using the same data set as used subsequently for MaxEnt we tested peculiar individual effects by sampling background points individually for each lynx in its spatial range. Randomly sampled background points facilitate presence-only modelling, and rather than representing species' absence they characterize the environment. Tested individual effects were negligible (random effect standard deviation $<1.5 \%$ of fixed effect intercept; Supplementary Table S2).

\section{Distribution modelling}

To model the potential distribution of the lynx population we used MaxEnt v. 3.3 (Phillips et al., 2010). MaxEnt attempts to calculate the probability distribution of a species' presence based on the constraints derived from environmental data at the presence locations. Following the principle of maximum entropy, the method remains as close as possible to uniform distribution. We used 10,00o background points to achieve the best possible results (Phillips \& Dudík, 2008; Barbet-Massin et al., 2012).

As the choice of resolution may affect model predictions (Guisan et al., 2007), we aimed to detect the most suitable grid cell size by calculating MaxEnt models under default settings for grids with edge lengths of 200, 500, 700, 1,000, 1,200 and 1,500 m. Following Guisan et al. (2007) we did not reduce the number of records by removing duplicate records in the same grid cell, but left sample size consistent between the models of various grid cell sizes. Each model was fitted and evaluated five times by $\mathrm{k}$-fold cross-validation, and thus each model had random samples of $80 \%$ lynx telemetry data for training and $20 \%$ for testing (Hirzel et al., 2006). Model performance was assessed by comparing the means of the area under the receiver operating characteristic curves (AUC). With presence-only (PO) modelling, $\mathrm{AUC}_{\mathrm{PO}}$ depicts the probability that a randomly chosen presence site will be ranked above a randomly chosen background site, whereby a random ranking (reflecting uniform distribution) achieves an $\mathrm{AUC}_{\mathrm{PO}}$ of 0.5 and a nearly perfect ranking approaches an $\mathrm{AUC}_{\mathrm{PO}}$ of 1 (but with the use of background 
locations it never achieves this; Wiley et al., 2003). $\mathrm{AUC}_{\mathrm{PO}}$ values vary with the spatial extent used to select background points as well as with the number of background points; because we only modified grid cell sizes but not the extent of the area or the number of background points, value comparison was possible.

In the model prediction we aimed for an output grid comprising a map of suitability scores. We used the logistic output to obtain a relative habitat suitability index of $0-1$, with o indicating unsuitable habitat and 1 indicating highly suitable habitat.

To select only raster cells for which we were able to make reliable predictions (i.e. cells characterized by a parameter composition similar to that of cells inside the model training area) we conducted a principal component analysis for all raster cells within the model prediction area, including the training area. Positions of raster cells were mapped in a scatterplot and a range of predictability was set on the basis of the distribution of raster cells characterizing the model training area. We predicted the model only on raster cells located within this range.

\section{Model evaluation}

To assess model accuracy by AUC we used monitoring data recorded for lynx in eastern Bavaria during 2005-2010, a data set independent of our GPS telemetry locations used for training the model. We recorded observations of lynx, using the categories of the Status and Conservation of the Alpine Lynx Population project (SCALP; Molinari-Jobin et al., 2012): category $\mathrm{C} 1$ denotes proof of lynx presence (dead or captured lynx, photographs, genetic samples); C2 accounts for confirmed observations (e.g. lynx kill or paw prints confirmed by an expert); $\mathrm{C}_{3}$ accounts for unconfirmed observations. We used $\mathrm{C}_{1}$ and $\mathrm{C}_{2}$ observations for model evaluation, resulting in a data set of 625 observations.

\section{Habitat quantification and connectivity}

To estimate the potential population size we needed information on the spatial requirements of lynx and on the amount of suitable habitat. We assessed spatial requirements by calculating 95\% MCPs (MCP95) for home range size in accordance with previous studies (Herfindal et al., 2005; Breitenmoser-Würsten et al., 2007), and chose $100 \%$ MCPs (MCP1oo) as well as $90 \%$ $\mathrm{MCPs}\left(\mathrm{MCP}_{90}\right)$ to obtain a range of population estimates. We selected time periods of 365 days and standardized the sampling frequency to one location per day.

To quantify available habitat it is necessary to convert continuous habitat suitability index values into binary results. There are various approaches that can be used to select a threshold (Liu et al., 2005). We used a new approach based on our model evaluation, which we considered to be the most consistent approach. We assumed all values representing suitable habitat were above the point at which the density of presence locations exceeded that of the background locations that characterized the environment.

For the potential population estimate we considered only suitable habitat patches larger than the mean home range of a female lynx, and calculated the percentages of suitable habitat cells within their spatial ranges (for MCP95, MCP9o, MCP100).

To assess the connectivity between suitable habitat patches we calculated least-cost paths based on a resistance grid at a resolution of $250 \times 250 \mathrm{~m}$. The resistance grid resulted from an overlay of the reciprocal resampled habitat suitability map (low habitat suitability index implies high resistance and vice versa; LaRue \& Nielsen, 2008) and a rasterized road layer (ESRI, Redlands, USA) with resistance values assigned according to road status (Hebblewhite et al., 2012). We assigned values within the range of the inverse habitat suitability, with the highest cost assigned to highways (Autobahn, resistance value $=1$ ), medium cost assigned to main roads (Bundesstraße, resistance value $=0.85$ ), and low cost assigned to municipal roads (Landstraße, resistance value $=0.7)$. Least-cost paths start at the centre of the patch of departure and end when the contour of the target patch is reached. We extracted the path lengths $\left(>_{5} \mathrm{~km}\right)$ between the patch contours to define the distances that lynx must travel when moving from one patch to another. For the assessment of patch connectivity we also considered $84 \mathrm{VHF}$ telemetry positions of a subadult dispersing lynx, recorded in 1997. The comparison of suitable patches with lynx occurrence in the region according to the latest status report (Kaczensky et al., 2013) resulted from a spatial overlay.

MaxEnt modelling, generalized linear mixed modelling, and home range computations were carried out in $R v$. 2.15.1 (R Development Core Team, 2012) using the packages dismo (Hijmans et al., 2012), lme4 (Bates et al., 2012), and adehabitatHR (Calenge, 2006). We used ArcMap v. 10.2 (ESRI, Redlands, USA) to calculate least-cost paths and create maps.

\section{Results}

\section{Distribution modelling}

We tested the MaxEnt model at various grid cell sizes and selected the $1,000 \times 1,000 \mathrm{~m}$ grid cell size for further analysis because it yielded the best model performance (Supplementary Table $S_{3}$ ). We limited the range of model predictability on the basis of the distribution of the model training area cells in the principal component analysis scatterplot (Fig. 2). Twenty-three percent of cells were thus excluded, including cells with high percentages of human settlements (human) or arable land (acre), which differed most from cells inside the model training area. 


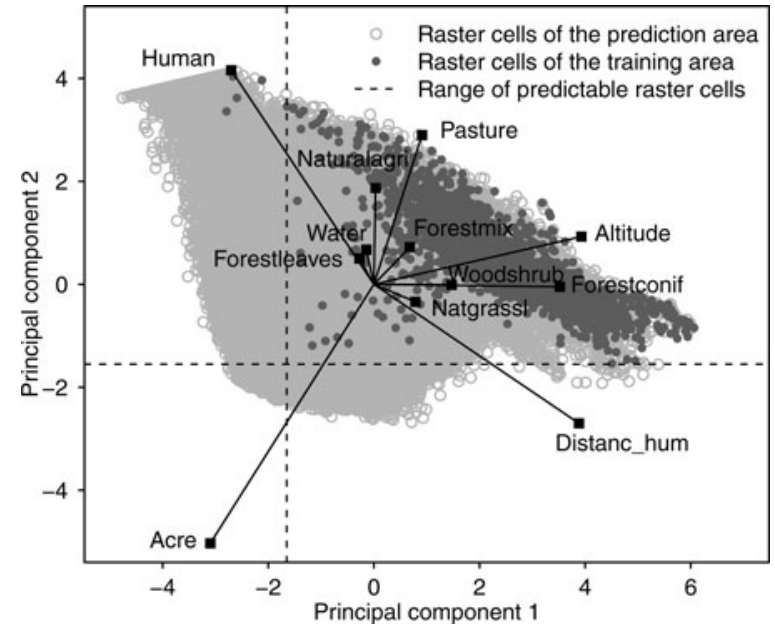

FIG. 2 Scatterplot resulting from principal component analysis of the model prediction area, including the training area (Fig. 1a). The lines are vectors of the environmental variables (Table 1).

Contributions of the specific environmental variables to the MaxEnt model are in Table 1. Response curves (Supplementary Fig. S1) provide more information on the relationship between environmental variables and the habitat suitability index. Anthropogenic open-space land-use types contributed most to the model and were negatively correlated with habitat suitability index. The occurrence of human settlements, industry or artificial surfaces (variable human; Supplementary Fig. S1) was linked to a comparably low habitat suitability index, and the response curve of variable distanc_hum demonstrated an increase in habitat suitability index with increasing distance to human settlements. Transitional woodland shrub and wetlands (variable woodshrub) and the three forest types broad-leaved, coniferous, and mixed provided comparatively suitable habitat, but for the variables forestmix (mixed forests) and forestconif (coniferous forest) the increase in habitat suitability index was marginal. High percentages of agricultural areas with significant natural vegetation or complex cultivation patterns (variable naturalagri) as well as high altitudes (variable altitude) resulted in a lower habitat suitability index. By projection of the trained MaxEnt model onto the model prediction area we created a habitat suitability map (Fig. 1b).

\section{Model evaluation and threshold selection}

Threshold-independent extrinsic model evaluation resulted in an $\mathrm{AUC}_{\mathrm{PO}}$ of 0.889 . However, habitat suitability index values are also of interest. Lynx were observed in areas with higher habitat suitability index values $($ median $=0.488$ ) than background locations (median $=0.083$; Wilcoxon test: $W=5,554,179, \mathrm{P}<0.0001$ ). The density plot (Fig. 3) displays similar information, namely that highest densities of observations were found in areas with habitat suitability

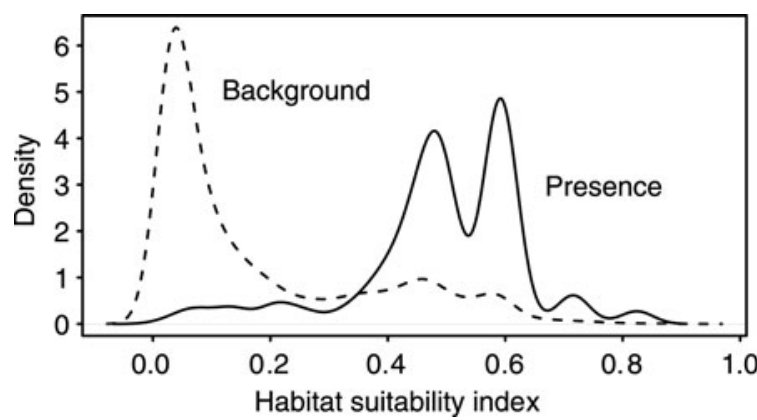

FIG. 3 Habitat suitability of 625 locations along the borders between Germany, the Czech Republic and Austria (Fig. 1a) where presence of lynx was confirmed, and 10,000 random background locations.

index values of c. 0.4-0.6; in contrast, background locations with the highest densities of observations had habitat suitability values of o.o-0.2. With the aim of quantifying available habitat we selected the intercept of the density curves, at a habitat suitability index of 0.35 , as our threshold and defined habitat suitability index values $\geq 0.35$ as suitable habitat. According to this threshold $89 \%$ of the Status and Conservation of the Alpine Lynx Population evaluation data comprise suitable habitat.

\section{Habitat quantification, connectivity and occupancy}

Mean home range sizes for male and female lynx were $445 \pm$ SD $128 \mathrm{~km}^{2}$ and $122 \pm S D 41 \mathrm{~km}^{2}$, respectively. Home ranges of males were significantly larger than those of females $(W=20, \mathrm{P}=0.016$; Table 2). For the lynx named Patrik we only considered a 300-day period because he shifted his home range after that period.

Percentages of suitable habitat cells within the home ranges (MCP95, Table 2) were $90 \%$ for females and $83 \%$ for males. We therefore assumed a habitat area of $110 \mathrm{~km}^{2}$ $(122 \times 0.9)$ for an average female and $369 \mathrm{~km}^{2}(445 \times 0.83)$ for an average male. Consequently, we calculated a density of 1.18 resident lynx per $100 \mathrm{~km}^{2}$ of suitable habitat, resulting in a potential population size of c. 142 individuals (distributed among 13 patches; Fig. 1b, Table 3). The percentage of suitable habitat cells within MCP10o (Table 2) was $89 \%$ for an average female lynx and $80 \%$ for a male. The percentage of suitable habitat cells within MCP9o (Table 2) was $90 \%$ for an average female and $84 \%$ for a male, resulting in an estimated population of 93-160 individuals (Table 3 ).

The results of the least-cost path analyses (Fig. 1b; Supplementary Table $\mathrm{S}_{4}$ ) depict the connectivity between these patches. The shortest least-cost path between these patches was $8 \mathrm{~km}$; the longest was $52 \mathrm{~km}$. Comparison of suitable habitat patches with reported lynx occurrence (Kaczensky et al., 2013) indicated permanent occupancy in 
TABLE 2 Home range estimations (based on minimum convex polygon, MCP) for radio-collared adult lynx in the Bohemian Forest Ecosystem (Fig. 1a) during 2005-2012, with name and sex of individuals, number of kittens, MCP9o, MCP95, MCP100, time period of data collection, and number of locations recorded.

\begin{tabular}{|c|c|c|c|c|c|c|c|}
\hline Name & Sex & No. of kittens & $\operatorname{MCP90~}\left(\mathrm{km}^{2}\right)$ & $\operatorname{MCP95}\left(\mathrm{km}^{2}\right)$ & $\operatorname{MCP} 100\left(\mathrm{~km}^{2}\right)$ & Time period (days) & No. of locations \\
\hline$\overline{\text { Ctirad }}$ & Male & & 322 & 462 & 688 & 365 & 351 \\
\hline Emanuel & Male & & 191 & 225 & 293 & 100 & 85 \\
\hline Kika & Male & & 216 & 257 & 369 & 365 & 347 \\
\hline Kubicka & Female & 2 & 130 & 145 & 187 & 365 & 334 \\
\hline Matilda & Female & 2 & 96 & 101 & 175 & 365 & 348 \\
\hline Milan & Male & & 509 & 532 & 693 & 365 & 335 \\
\hline Nimo & Male & & 507 & 585 & 622 & 365 & 288 \\
\hline Nora & Female & 1 & 142 & 166 & 186 & 365 & 217 \\
\hline Patrik & Male & & 354 & 389 & 625 & 300 & 267 \\
\hline Tessa & Female & 2 & 64 & 77 & 127 & 365 & 354 \\
\hline \multicolumn{3}{|c|}{ Mean female } & 108 & 122 & 187 & & \\
\hline \multicolumn{3}{|c|}{ Mean male (excluding Emanuel ${ }^{\star}$ ) } & 382 & 445 & 599 & & \\
\hline
\end{tabular}

${ }^{\star}$ Excluded because GPS locations were recorded only on 100 days

TABLE 3 Estimated area of suitable lynx habitat patches in the study area (Fig. 1a), with potential number of lynx, and whether occupancy is permanent or sporadic.

\begin{tabular}{lccl}
\hline $\begin{array}{l}\text { Patch region } \\
\text { (Fig. 3) }\end{array}$ & $\begin{array}{c}\text { Area of suitable } \\
\text { habitat }\left(\mathrm{km}^{2}\right)\end{array}$ & $\begin{array}{l}\text { Potential no. of } \\
\text { lynx }{ }^{1}\left(\text { range }^{2}\right)\end{array}$ & $\begin{array}{l}\text { Occupancy according to Kaczensky et al. }(2013)(\text { No. of } 10 \times 10 \mathrm{~km} \\
\text { grid cells with permanent presence overlaying the patch) }\end{array}$ \\
\hline Bohemian Forest & 3,904 & $46(31-52)$ & Permanent presence $(40)$ \\
Erz Mountains & 1,726 & $20(13-23)$ & Sporadic occurrence \\
Forest Quarter & 1,300 & $15(10-17)$ & Permanent presence (3) \\
Krkonoše Mountains & 954 & $11(7-12)$ & Sporadic occurrence \\
Upper Palatinate Forest & 937 & $11(7-12)$ & Permanent presence $(5)$ \\
Franconian Forest & 690 & $8(5-9)$ & No occurrence detected \\
Slavkovský les & 686 & $8(5-9)$ & Sporadic occurrence \\
Brdy & 514 & $6(4-6)$ & Permanent presence $(2)$ \\
Fichtel Mountains & 481 & $5(3-6)$ & Sporadic occurrence \\
Patch CZ South & 385 & $4(3-5)$ & Sporadic occurrence \\
Northern Franconian Jura & 326 & $3(2-4)$ & No occurrence detected \\
Labské pískovce & 289 & $3(2-3)$ & Sporadic occurrence \\
Patch CZ North & 223 & $2(1-2)$ & No occurrence detected \\
Total & 12,415 & $142(93-160)$ & \\
\hline
\end{tabular}

${ }^{1}$ Based on 1.18 per $100 \mathrm{~km}^{2}$ suitable habitat

${ }^{2}$ Based on $0.81-1.34$ per $100 \mathrm{~km}^{2}$ suitable habitat

four patches, sporadic occurrence in six patches, and no occurrence in three patches (Table 3).

\section{Discussion}

In our study area we estimated a habitat carrying capacity for a lynx population of c. 142 individuals (based on population estimates of 93 (MCP100) to 160 (MCP9o) individuals), distributed across 13 patches (Fig. 1b, Table 3). This estimate refers to territorial lynx and does not include the population of subadults, which can be $5-35 \%$ of the resident population (Jędrzejewski et al., 1996; Zimmermann \& Breitenmoser, 2007). A spatial comparison of potential and actual lynx distribution with the latest status report
(Kaczensky et al., 2013) revealed permanent lynx presence in four of these patches (Bohemian Forest, Upper Palatinate Forest, Brdy, Forest Quarter; Table 3). Of these, there is a permanent patch-wide distribution of lynx only in the Bohemian Forest. This represents the source of the population and includes the Bavarian Forest National Park and the Šumava National Park, which have been shown to be of significant importance for lynx conservation in the region (Müller et al., 2014). Nine patches $\left(5,760 \mathrm{~km}^{2}\right.$ in total) are not permanently occupied by lynx.

We analysed least-cost paths to assess connectivity between suitable habitat patches and considered available information on regional lynx distribution. In Bavaria there is evidence (Status and Conservation of the Alpine Lynx Population $\mathrm{C}_{1}$ and $\mathrm{C}_{2}$ categories) that lynx are able to 
reach the Fichtel Mountains and Franconian Forest in the north-west of our model prediction area (Fig. 1b). Connectivity to Brdy is not immediately apparent but VHF positions of a subadult lynx reveal that Brdy is accessible (Supplementary Fig. S2). Reported lynx distribution (Kaczensky et al., 2013) confirms accessibility of the remaining patches except for Northern Franconian Jura and Patch CZ North (Table 3). Moreover, data on lynx dispersal in Switzerland (2-97 km; Zimmermann et al., 2005) and Scandinavia (3-428 km; Samelius et al., 2012) indicate the ability of lynx to access suitable patches in our model prediction area. The roads located between suitable patches in our model prediction area are mostly main roads and municipal roads, which pose risks but not barriers for lynx. Highway A9, which separates the Franconian Forest from the other patches, may be more difficult to cross but a category $\mathrm{C} 1 \mathrm{ob}$ servation indicated that crossing is possible. Thus, we assume all patches are reachable for lynx, but highlight that fragmentation of patches needs to be considered in landscape planning to prevent degradation of connectivity. The habitat map (raster file available on request) may be used for this purpose by administrators and wildlife managers, and also as a basis for planning lynx reintroductions.

Besides increasing numbers of lynx and thus raising the probability of connecting with isolated populations, reintroductions help to overcome deleterious effects of any potential inbreeding depression (Johnson et al., 2010). The genetic status of the Bohemian-Bavarian population is unknown as genetic analyses are lacking. Nevertheless, camera-trap data (Supplementary Table S5$_{5}$ f for methods see Weingarth et al., 2012) indicate substantial reproduction in the Bohemian Forest patch, and lynx dispersal is supported by sporadic occurrence in most patches. Despite this, lynx are apparently unable to establish permanent subpopulations there, and in line with other authors (Wölfl et al., 2001; Červený et al., 2002; Molinari-Jobin et al., 2010; Müller et al., 2014) we assume that illegal killing is the most likely factor limiting the distribution of the population.

Our home-range-based population estimate is higher than that of Schadt et al. (2002a,b), which extrapolated data for Swiss lynx to Germany and thus had predictive uncertainty. We estimated there was up to $12,415 \mathrm{~km}^{2}$ of suitable habitat in the prediction area. Schadt et al. (2002a,b) estimated a smaller total area of suitable habitat along the Austrian-German-Czech border but they did not consider the entire range of the Bohemian-Bavarian population but rather the different spatial requirements of lynx. Schadt et al. (2002b) assumed an overlap of one male per female lynx within $99 \mathrm{~km}^{2}$ and reported an approximate estimate of 100 individuals. Schadt et al. (2002a) modelled 77 potential territories, considering the spatial requirements of Swiss lynx. Our analyses resulted in a higher potential population estimate of 142 (93-160). For further comparisons of population estimation, a habitat-based approach that does not require thresholding habitat suitability data (Boyce \& McDonald, 1999) would be informative. Such an approach has been applied in large carnivore conservation (Hebblewhite et al., 2012), but a reliable estimate of the size of the existing population as well as a detailed delineation of its range are needed as references.

In accordance with results of previous studies (Schadt et al., 2002b; Niedziałkowska et al., 2006) our MaxEnt model of lynx distribution indicated that lynx avoid areas close to human settlements or with intense anthropogenic disturbance. Similarly, Basille et al. (2009) reported that lynx avoid agricultural areas, but in contrast to our study they did not find that lynx avoided areas close to artificial areas. Previous studies have emphasized the importance of forest for lynx (Schadt et al., 2002b; Niedziałkowska et al., 2006; Basille et al., 2009; Müller et al., 2014). Our model was not primarily determined by variables linked to forest, possibly because of the comparatively high availability of forest (66\% of the model training area). Our results also indicated that in the study area lynx preferred areas of lower altitude, which is in accordance with the results of Basille et al. (2009) and matches the increasing density of roe deer with decreasing altitude (Heurich et al., 2015). Prey density could not be included in the model because no transnational data were available, but we expect prey densities in the model prediction area to be equivalent to or higher than within the forest-dominated model training area. We base this assumption on the roe deer density index in Bavaria (Hothorn et al., 2012) and on previous records of high roe deer densities in less-forested areas (Melis et al., 2009). An advantage of the use of coarse transnational data was the ability to consider the entire BohemianBavarian population, unlike the study of Müller et al. (2014), which was restricted to Bavaria. However, we are aware that we disregarded fine-scale habitat characteristics of forests, such as essential cover for den sites, daily resting sites (Podgórski et al., 2008), and cover from hunting (Dickson \& Beier, 2002). Considering the intentions of our study, however, we assume these characteristics to be negligible as forest should provide them sufficiently.

We used MaxEnt to assess habitat suitability, a presence-only method that is designed to make predictions based on incomplete data (Elith et al., 2011). The predictive accuracy of MaxEnt is high, which makes it consistently competitive among the highest-performing methods (Guisan et al., 2007; Phillips \& Dudík, 2008). MaxEnt was not developed primarily for use with telemetry data (Baldwin, 2009), which are characterized by repeated sampling of one individual. However, as reception of GPS data on lynx locations did not vary with habitat the detection probability of telemetry data is consistent across a study area and the data represent a random sample of presence locations, thereby meeting the basic assumptions of MaxEnt (Yackulic et al., 2013). 
The model was complex because lynx presence could not be associated with a particular variable, but evaluation revealed good model performance according to the $\mathrm{AUC}_{\mathrm{PO}}$. Qualification of the AUC as a measure of model accuracy has been criticized (Yackulic et al., 2013); nevertheless, our approach of thresholding based on model evaluation categorized $89 \%$ of the Status and Conservation of the Alpine Lynx Population data correctly. Our approach therefore equals a cut-point probability at $89 \%$, compared with the cut-point probabilities of Hebblewhite et al. (2012), who chose $85 \%$ with Amur tiger Panthera tigris altaica tracks, and Hebblewhite et al. (2011), with 90\% for Far Eastern leopards Panthera pardus orientalis.

As the scale of predictor variables affects the model prediction, we evaluated model performance for various grid cell sizes. Our results indicated that the habitat model performed best using a grid cell of $1 \mathrm{~km}^{2}$ and that, in line with Guisan et al. (2007), a lower resolution does not necessarily imply poorer performance. In contrast, the model performed best at a grid cell size five times coarser than the smallest resolution tested. From an ecological point of view, a comparably coarse grid cell size makes sense when modelling habitat of a species with large spatial requirements, such as the lynx, and facilitates the necessarily wideranging conservation planning (Chapron et al., 2014). Overly coarse grain is not effective, however; model performance decreased when a grid cell size of $>1 \mathrm{~km}^{2}$ was used. A study on the sensitivity of MaxEnt to scale differences indicated that the maximum grain size should be c. $1.5 \mathrm{~km}$ (Song et al., 2013).

We assume our model predictions are reasonable as we did not extrapolate our model beyond the ranges of variable values used to train it. Others have cautioned against going beyond the calibration range (Pearson et al., 2006; Hirzel \& Le Lay, 2008), yet this is rarely considered in model applications. We benefited from lynx data originating from a part of the model prediction area, and by defining a range of predictability we were able to predict $77 \%$ of cells within the study area.

The applied least-cost path method estimates the distances that lynx have to overcome between suitable habitat patches, but assumes that an individual has a planned destination when leaving a patch. We acknowledge that a more complex stochastic movement simulator without this assumption could map dispersal paths more precisely (Palmer et al., 2011). As we intended to estimate the distances rather than determine the exact paths, we believe the least-cost path method is sufficient.

From our results we draw some conclusions regarding the conservation of a characteristic Central European lynx population with the potential to connect small and isolated populations. Firstly, despite connectivity, the current distribution of the Bohemian-Bavarian lynx population is not in equilibrium with available habitat, which in line with
Chapron et al. (2014) indicates that factors other than habitat limit the distribution, with illegal killing being the most likely factor. We thus recommend focusing future research on dispersing subadult lynx, with the aim of increasing acceptance of lynx by people. Secondly, the potential carrying capacity of habitat in the study area is not sufficient for a long-term viable population, which according to expert opinion should comprise c. 500 individuals (Linnell et al., 2008). Thus, the population requires connectivity to other populations (i.e. Czech Carpathian, German Harz, and Austrian Alpine populations). Thirdly, patches of suitable habitat are fragmented; their distribution needs to be considered in landscape and road development to prevent further fragmentation, and when planning and locating sites for lynx reintroduction.

\section{Acknowledgements}

This study is part of the Eurasian lynx project of the Bavarian Forest National Park, Department of Research and Documentation. Financial support was provided by EU Programme Interreg IV (EFRE Ziel 3). We thank O. Vojtěch, J. Mokrý, H. Burghart, M. Gahbauer, and other staff of Šumava National Park and Bavarian Forest National Park for their help with field work, and F. Gutkowski for analyses of GPS collar performance. We also thank Karen A. Brune for improving the writing of the manuscript, and Miha Krofel and three anonymous reviewers for their helpful comments.

\section{References}

Andrén, H., Linnell, J.D.C., Liberg, O., Andersen, R., Danell, A., KARLSSON, J. et al. (2006) Survival rates and causes of mortality in Eurasian lynx (Lynx lynx) in multi-use landscapes. Biological Conservation, 131, 23-32.

BALDWIN, R.A. (2009) Use of maximum entropy modeling in wildlife research. Entropy, 11, 854-866.

Barbet-Massin, M., Jiguet, F., Albert, C.H. \& Thuiller, W. (2012) Selecting pseudo-absences for species distribution models: how, where and how many? Methods in Ecology and Evolution, 3, 327-338.

Basille, M., Herfindal, I., Santin-Janin, H., Linnell, J.D.C., Odden, J., Andersen, R. et al. (2009) What shapes Eurasian lynx distribution in human dominated landscapes: selecting prey or avoiding people? Ecography, 32, 683-691.

Bates, D., Maechler, M. \& Bolker, B. (2012) lme4: Linear mixed-effects models using $\mathrm{S}_{4}$ classes. R package version o.999999-o. Http://cran.r-project.org/package=lme4 [accessed 20 May 2015].

Boyce, M.S. \& McDonald, L.L. (1999) Relating populations to habitats using resource selection functions. Trends in Ecology \& Evolution, 14, 268-272.

Breitenmoser-Wúrsten, C., Zimmermann, F., Molinari-Jobin, A., Molinari, P., Capt, S., Vandel, J.-M. et al. (2007) Spatial and social stability of a Eurasian lynx Lynx lynx population: an 
assessment of 10 years of observation in the Jura Mountains. Wildlife Biology, 13, 365-38o.

Calenge, C. (2006) The package "adehabitat" for the R software: a tool for the analysis of space and habitat use by animals. Ecological Modelling, 197, 516-519.

Červený, J., Koubek, P. \& Bufka, L. (2002) Eurasian lynx (Lynx $\operatorname{lyn} x$ ) and its chance for survival in Central Europe: the case of the Czech Republic. Acta Zoologica Lituanica, 12, 428-432.

Chapron, G., Kaczensky, P., Linnell, J.D.C., von Arx, M., Huber, D., ANDRÉN, H. et al. (2014) Recovery of large carnivores in Europe's modern human-dominated landscapes. Science, 346, 1517-1519.

Dickson, B.G. \& Beier, P. (2002) Home-range and habitat selection by adult cougars in southern California. Journal of Wildlife Management, 66, 1235-1245.

Elith, J., Phillips, S.J., Hastie, T., Dudík, M., Chee, Y.E. \& Yates, C.J. (2011) A statistical explanation of MaxEnt for ecologists. Diversity and Distributions, 17, 43-57.

European Environment Agency (2012) Corine land coverGermany. Http://www.corine.dfd.dlr.de/intro_en.html [accessed 20 May 2015].

Fischer, J. \& Lindenmayer, D.B. (2007) Landscape modification and habitat fragmentation: a synthesis. Global Ecology and Biogeography, $16,265-280$.

Guisan, A., Graham, C.H., Elith, J. \& Huettmann, F. (2007) Sensitivity of predictive species distribution models to change in grain size. Diversity and Distributions, 13, 332-340.

Guisan, A. \& Zimmermann, N.E. (200o) Predictive habitat distribution models in ecology. Ecological Modelling, 135, 147-186.

Hebblewhite, M., Miquelle, D.G., Murzin, A.A., Aramilev, V.V. \& Pikunov, D.G. (2011) Predicting potential habitat and population size for reintroduction of the Far Eastern leopards in the Russian Far East. Biological Conservation, 144, 2403-2413.

Hebblewhite, M., Zimmermann, F., Li, Z., Miquelle, D.G., $Z_{H A N G}, M .$, SUN, H. et al. (2012) Is there a future for Amur tigers in a restored tiger conservation landscape in Northeast China? Animal Conservation, 15, 579-592.

Herfindal, I., Linnell, J.D.C., Odden, J., Birkeland Nilsen, E. \& Andersen, R. (2005) Prey density, environmental productivity and home-range size in the Eurasian lynx (Lynx lynx). Journal of Zoology, 265, 63-71.

Heurich, M., Brand, T.T.G., KaAndorp, M.Y., Šustr, P., Müller, J. \& REINEKING, B. (2015) Country, cover or protection: what shapes the distribution of red deer and roe deer in the Bohemian Forest Ecosystem? PLoS ONE, 10(3), e012096o.

Heurich, M., Möst, L., Schauberger, G., Reulen, H., Šustr, P. \& Hothorn, T. (2012) Survival and causes of death of European roe deer before and after Eurasian lynx reintroduction in the Bavarian Forest National Park. European Journal of Wildlife Research, 58, $567-578$.

Hijmans, R.J., Cameron, S.E., Parra, J.L., Jones, P.G. \& Jarvis, A. (2005) Very high resolution interpolated climate surfaces for global land areas. International Journal of Climatology, 25, 1965-1978.

Hijmans, R.J., Phillips, S., Leathwick, J. \& Elith, J. (2012) dismo: Species distribution modeling. R package version $0.7-17$. Http:// cran.r-project.org/package $=$ dismo [accessed 20 May 2015].

Hirzel, A.H. \& Le Lay, G. (2008) Habitat suitability modelling and niche theory. Journal of Applied Ecology, 45, 1372-1381.

Hirzel, A.H., Le Lay, G., Helfer, V., Randin, C. \& Guisan, A. (2006) Evaluating the ability of habitat suitability models to predict species presences. Ecological Modelling, 199, 142-152.

Hothorn, T., Brandl, R. \& Müller, J. (2012) Large-scale model-based assessment of deer-vehicle collision risk. PLoS ONE, 7 (2), e29510.
Jedrzejewski, W., Jedrzejewska, B., Okarma, H., Schmidt, K., Bunevich, A.N. \& MiŁkowski, L. (1996) Population dynamics (1869-1994), demography, and home ranges of the lynx in Białowieża Primeval Forest (Poland and Belarus). Ecography, 19, 122-138.

Johnson, W.E., Onorato, D.P., Roelke, M.E., Land, E.D., Cunningham, M., Belden, R.C. et al. (2010) Genetic restoration of the Florida panther. Science, 329, 1641-1645.

Kaczensky, P., Chapron, G., von Arx, M., Huber, D., Andrén, H. \& Linnell, J.D.C. (2013) Status, Management and Distribution of Large Carnivores-Bear, Lynx, Wolf \& Wolverine-in Europe. Report to the European Commission.

LaRue, M.A. \& Nielsen, C.K. (2008) Modelling potential dispersal corridors for cougars in midwestern North America using least-cost path methods. Ecological Modelling, 212, 372-381.

Linnell, J.D.C., Salvatori, V. \& Boitani, L. (2008) Guidelines for Population Level Management Plans for Large Carnivores in Europe. A Large Carnivore Initiative for Europe report prepared for the European Commission.

Linnell, J.D.C., Swenson, J.E. \& Andersen, R. (2001) Predators and people: conservation of large carnivores is possible at high human densities if management policy is favourable. Animal Conservation, 4, 345-349.

Liu, C., Berry, P.M., Dawson, T.P. \& Pearson, R.G. (2005) Selecting thresholds of occurrence in the prediction of species distributions. Ecography, 28, 385-393.

Melis, C., Jędrzejewska, B., Apollonio, M., Bartoń, K.A., Jędrzejewski, W., Linnell, J.D.C. et al. (2009) Predation has a greater impact in less productive environments: variation in roe deer, Capreolus capreolus, population density across Europe. Global Ecology and Biogeography, 18, 724-734.

Molinari-Jobin, A., Kéry, M., Marboutin, E., Molinari, P., Koren, I., FuxJäGer, C. et al. (2012) Monitoring in the presence of species misidentification: the case of the Eurasian lynx in the Alps. Animal Conservation, 15, 266-273.

Molinari-Jobin, A., Marboutin, E., Wölfl, S., Wölfl, M., Molinari, P., Fasel, M. et al. (2010) Recovery of the Alpine lynx Lynx lynx metapopulation. Oryx, 44, 267-275.

Múller, J., Wölfl, M., Wölfl, S., Múller, D.W.H., Hothorn, T. \& HeURICH, M. (2014) Protected areas shape the spatial distribution of a European lynx population more than 20 years after reintroduction. Biological Conservation, 177, 210-217.

NiedziaŁkowska, M., Jędrzejewski, W., MysŁajek, R.W., Nowak, S., JędrZejewska, B. \& Schmidt, K. (2006) Environmental correlates of Eurasian lynx occurrence in Polandlarge scale census and GIS mapping. Biological Conservation, 133, 63-69.

Palmer, S.C.F., Coulon, A. \& Travis, J.M.J. (2011) Introducing a 'stochastic movement simulator' for estimating habitat connectivity. Methods in Ecology and Evolution, 2, 258-268.

Pearson, R.G., Thuiller, W., Araújo, M.B., Martinez-Meyer, E., Brotons, L., McClean, C. et al. (2006) Model-based uncertainty in species range prediction. Journal of Biogeography, 33, 1704-1711.

Phillips, S.J. \& Dudík, M. (2008) Modeling of species distributions with Maxent: new extensions and a comprehensive evaluation. Ecography, 31, 161-175.

Phillips, S., Dudík, M. \& Schapire, R. (2010) Maxent software, v.3.3. Https://www.cs.princeton.edu/ schapire/maxent/ [accessed 20 May 2015].

Podgórski, T., Schmidt, K., Kowalczyk, R. \& Gulczyńska, A. (2008) Microhabitat selection by Eurasian lynx and its implications for species conservation. Acta Theriologica, 53, 97-110. 
Podolski, I., Belotti, E., Bufka, L., Reulen, H. \& Heurich, M. (2013) Seasonal and daily activity patterns of free-living Eurasian lynx Lynx lynx in relation to availability of kills. Wildlife Biology, 19, 69-77.

R Development Core Team (2012) R: A Language and Environment for Statistical Computing. R Foundation for Statistical Computing, Vienna, Austria.

Ripple, W.J., Estes, J.A., Beschta, R.L., Wilmers, C.C., Ritchie, E. G., Hebblewhite, M. et al. (2014) Status and ecological effects of the world's largest carnivores. Science, 343, 151-163.

Samelius, G., Andrén, H., Liberg, O., Linnell, J.D.C., Odden, J., Ahlqvist, P. et al. (2012) Spatial and temporal variation in natal dispersal by Eurasian lynx in Scandinavia. Journal of Zoology, 286, $120-130$.

Schadt, S., Knauer, F., Kaczensky, P., Revilla, E., Wiegand, T. \& TREPL, L. (2002a) Rule-based assessment of suitable habitat and patch connectivity for the Eurasian lynx. Ecological Applications, 12, 1469-1483.

Schadt, S., Revilla, E., Wiegand, T., Knauer, F., Kaczensky, P., Breitenmoser, U. et al. (2002b) Assessing the suitability of central European landscapes for the reintroduction of Eurasian lynx. Journal of Applied Ecology, 39, 189-203.

SCHMidt, K. (2008) Factors shaping the Eurasian lynx (Lynx lynx) population in the north-eastern Poland. Nature Conservation, 65 , 3-15.

Seebach, L.M., Strobl, P., San Miguel-Ayanz, J. \& BASTRUP-BIRK, A. (2011) Identifying strengths and limitations of pan-European forest cover maps through spatial comparison. International Journal of Geographical Information Science, 25, 18651884

Song, W., Kim, E., Lee, D., Lee, M. \& Jeon, S.-W. (2013) The sensitivity of species distribution modeling to scale differences. Ecological Modelling, 248, 113-118.

Weingarth, K., Heibl, C., Knauer, F., Zimmermann, F., Bufka, L. \& Heurich, M. (2012) First estimation of Eurasian lynx (Lynx lynx) abundance and density using digital cameras and capture-recapture techniques in a German national park. Animal Biodiversity and Conservation, 35.2, 197-207.
Wiley, E.O., McNyset, K.M., Peterson, A.T., Robins, C.R. \& STEWART, A.M. (2003) Niche modeling perspective on geographic range predictions in the marine environment using a machine-learning algorithm. Oceanography, 16, 120-127.

Wölfl, M., BufKa, L., ČervenÝ, J., Koubek, P., Heurich, M., Habel, H. et al. (2001) Distribution and status of lynx in the border region between Czech Republic, Germany and Austria. Acta Theriologica, 46, 181-194.

Yackulic, C.B., Chandler, R., Zipkin, E.F., Royle, J.A., Nichols, J.D., Campbell Grant, E.H. \& Veran, S. (2013) Presence-only modelling using MAXENT: when can we trust the inferences? Methods in Ecology and Evolution, 4, 236-243.

Zimmermann, F. \& Breitenmoser, U. (2007) Potential distribution and population size of the Eurasian lynx Lynx lynx in the Jura Mountains and possible corridors to adjacent ranges. Wildlife Biology, 13, 406-416.

Zimmermann, F., Breitenmoser-Würsten, C. \& Breitenmoser, U. (2005) Natal dispersal of Eurasian lynx (Lynx lynx) in Switzerland. Journal of Zoology, 267, 381-395.

\section{Biographical sketches}

Nora MAGG develops guidelines for conservation of faunistic species in managed forests. JÖRG MULLER is a conservation biologist interested in the effects of varying management intensities on forest biodiversity. Christoph Heibl works on data analyses in ecology and evolutionary biology. KLAUS HACKLÄNDER focuses on wildlife ecology and develops management strategies for sustainable use, conservation or control of wildlife species. SyBiLle W ÖLFL works on lynx conservation and management. MANFRED W ÖLFL works on wildlife management, with a focus on human dimensions and conflict mitigation. LUDEK BUFKA is a zoologist specializing in research and conservation of large carnivores. JAROSLAV ČERVENÝ focuses on wildlife biology and the ecology of mammals. MARCO HEURICH is interested in the ecology and conservation of natural forest ecosystems. 